\title{
Self- Liberation Vs Self- Renunciation in Hedda Gabler
}

\author{
Ms. Swarna \\ Research Scholar \\ C.C.S.University Campus \\ Meerut, India \\ swarnasingh206@gmail.com
}

\begin{abstract}
Henrik Ibsen, by using Hedda as the heroine or anti-heroine of the play Hedda Gabler, was clearly attacking a culture which stifled women's potential and fostered the feelings of entrapment and desperation that Hedda experiences. For all her flaws, the character of Hedda Gabler serves as a potent reminder of the individual's complex relationship to society and how we today reconcile our own needs with the roles and responsibilities expected of us. In following Hedda's psychological descent throughout the play, Ibsen was plainly criticizing the lack of acceptable life choices and opportunities for women in nineteenth-century society. The purpose of my research paper is to justify Hedda's act of suicide as an act of self-liberation vs self-renunciation. Her downfall is ultimately her own doing-she makes the mistake of marrying George for the wrong reasons but she is also a heavily flawed character who unsuccessfully manipulates people in an attempt to negotiate her own weakness. She chooses death not because of any insight she has gained from her mistakes but because she cannot face the consequences of her action. Thus, Hedda's death is tragic because it is an act of self-renunciation: she is free spirit who cannot be tamed by conventional society.
\end{abstract}


Keywords: Hedda Gabler, Psychological Descent, Opportunities, Self-Renunciation, Existence, Consequences, Conventional Society.

Ibsen's knowledge of humanity is nowhere more obvious than in his portrayal of women. He amazes one by his painful introspection; he seems to know them better than they know themselves. (Finney, Gail. "Ibsen and Feminism". p. 93)

Ibsen has used realistic or naturalistic techniques of the outstanding social plays in 1890 when he wrote Hedda Gabler. Although, the major focus in the play is on a deep-rooted psychological problem i.e. self-liberation vs self-renunciation, it is not difficult to discover some social significance. Hedda has much intellectual freedom, but her emotions cannot be managed enough so that she can make use of this freedom. The portrayal of Hedda may be considered as a study of the effects of the emancipation of women. This interpretation is supported by the fact that Henrik Ibsen patterned Hedda's character after an eighteen-year-old Austrian Eomilie Bardach who wished to devote her life to taking married men away from their wives. Ibsen was attracted by this woman in 1889, for a brief time. He continued a correspondence with her but finally settled upon an objective study of her. The outcome of this friendship was the play Hedda Gabler.

Many of the analysis of Hedda Gabler of the 1890s and the early 1900s continue to be expressed today. For F.L.Lucas, Hedda is a twentieth century New Woman, "the idle, emancipated woman and what she is to do with her emancipation, the devil only knows" (Lucas, F.L. "The Drama of Ibsen and Strindberg". p. 240). For James Huneker, she is the deficient woman, 'the loveless woman'. (Templeton, Joan. Ibsen's Women. p. 206) The split between those who want art to be elevating or at least happy and those who accept grim portrait of reality continues. Of course, new ways of reading the play have arisen in the interval; for example, Freudian critics interpret Hedda as sexually repressed or frigid, and Marxist critics emphasize the repression of bourgeois society, which is represented by the 
Tesmans.

Other described her as an example of the New Woman, a female character common in fiction in 1890 s, when women were boldly demanding equality with men.

"The new woman typically values self-fulfillment and independence rather than the stereotypically feminine ideal of self-sacrifice, believes in legal and sexual equality, often remains single because of the difficulty of combining such equality with marriage; is more open about her sexuality than the old woman; is well educated and reads a great deal; has a job; is athletic or otherwise physically, vigorous and according prefers comfortable clothes (sometimes male attire) to tradition female garb". (Finney, Gail. "Ibsen and Feminism". pp. 99-100)

The lines show that Ibsen supported greater freedom for women and presented his belief in his play. In his notes for A Doll's House, he wrote: "A woman cannot be herself in contemporary society, it is an exclusively male society with laws drafted by men, and with counsel and judges who judge feminine conduct from the male point of views". (Ibid. p.90) Ibsen's contemporaries related him with the New Woman and Women's rights. The New Woman was the term used at the end of 19th century to describe women who were pushing against the restrictions which society imposed on women today she might be called a liberated woman or feminist. How identified Ibsen was with the issue is suggested by Max Beerbohm's exaggerated, if witty statement, "The New Woman sprang fully armed from Ibsen's brain". (Beerbohm, Max. "An hypocrisy in Playgoing”. pp. 277-81)

Although many feminists still argue that women yet to accomplish their liberation, enfranchisement and great freedom have resulted from the revolutionary changes that have occurred in this century. .

In Hedda Gabler we are introduced to Hedda Gabler as the daughter of venerated 
General Gabler and as a woman born into highly wealthy aristocratic family. Though having lived a pampered life, she thought her time as a single woman was growing thin, leading her to marry George Tesman, a man she actually no longer has feelings for if indeed she ever did. Throughout the rest of Henrik Ibsen's play Hedda Gabler we notice how Hedda's obsession with freedom and free will conflict with the norms of nineteenth century society which surrounds her, leading her to manipulate those around her, and finally her own death, in other words, self-renunciation, the main theme of the play.

To understand the naturalistic philosophy in Hedda Gabler, it is necessary to understand the story and the characters of the play first. George Tesman, a scholar, Hedda Tesman, his wife; Miss Juliana Tesman, his aunt; Mrs. Thea Elvsted, a former school girl with Hedda, and at one time a friend of George; Judge Brack, a friend of the Tesman; Eilert lovborg, a brilliant but alcoholic Scholar, formerly a friend of Hedda and George; and Berta, the Tesmans' servant. The setting is the drawing room of the Tesmans' villa in Christiania (now Oslo), Norway.

The play opens with a conversation between Juliana and Berta, the Tesmans' servants. Through this dialogue, Ibsen shows the necessary background information about the play. George and Hedda have just came back home from a six-month wedding tour through Europe, during which George received a doctorate.

Hedda enters, complaining first of the excessive sunshine and fresh air, and then of the servant's old bonnet on a chair. Juliana is slightly insulted, because this is her hat which Hedda was referring to as being the servant's. However, she hides her feelings, wishing to make the visit a nice one.

Mrs. Thea Elvsted comes in later and talks about her marriage to Sheriff Elvsted and about her stepchildren, to whom Eilert Lovborg had been appointed tutor. While George goes into the next room to write a letter to Lovborg, Mrs, Elvsted informs Hedda how she has been 
helping Eilert for the last two years with his books. She also tells that Eilert's memory cannot be cleared of a woman who threatened to shoot him with a pistol when they parted. Mrs. Elvsted thinks the woman to be a red-haired singer who is in town again.

Judge Brack comes to inform George that his appointment as professor may depend upon a competition with Eilert Lovborg. George is rather upset by this news, while Hedda says, quite nonchalantly, that she is the most curious to see who wins. After the Judge has departed, George shows his concern about this matter to Hedda. However, she is only disturbed because she cannot have the liveried footman and saddle horse she was promised. She shows unconcern by retiring to her room to play with the pistols which her father, General Gabler, had given her.

In the beginning of Act II as Hedda stands by the door, loading a pistol, she points it and fires as Judge Brack comes nearer. He is scared and annoyed by her actions and takes the pistol from her. They later have a confidential discussion during which she confesses that she did not marry George for love, but because she thought he could provide the most material assets for her. She admits the following:

"So you see it was this enthusiasm for Secretary Faulk's villa that first constituted a bond of sympathy between George Tesman and me. From that came our engagement and our marriage, and our wedding journey, and all the rest of it. Well, well, my dear Judge as you made your bed so you must lie, I could almost say". (Ibsen, Henrik. Hedda Gabler. Act II, 246)

Judge Brack expresses that he is interested in a "triangular friendship." (Ibid. p. 245) Hedda is disinterested and makes it clear to him that there is only one thing she is fit for; boring herself to death.

George and Lovborg then enter the house. Lovborg informs Tesman that he will not contest the professorship, but will deliver a series of lectures later, to assure only a "moral 
victory" (Ibid. p. 256) over his rival. Tesman leaves the room, and Lovborg and Hedda remain to have a confidential conversation. The two were at one time close friends, but she confesses that she broke off the friendship when Eilert became too serious. Through their dialogues it is clear that Hedda was the woman who had threatened to shoot him. Mrs. Elvsted enters and their conversation is stopped.

Judge Brack declares that he is having a party that night and invites Eilert to attend. Eilert refuses, but Hedda motivates him to go. He then decides to accompany Brack and Tesman, and asserts that he will return at about ten o'clock to take Thea home.

After the night has passed, early in the morning, Hedda and Mrs. Elvsted have been waiting all night for the home coming of George and Eilert. Hedda, who has had a full night's rest without tension, tells Thea that there is nothing about which to worry. George eventually enters and informs Hedda about how Eilert became drunk and lost his manuscript, which he found by the side of the road. He tells that he did not return it immediately because Eilert was in no condition to take care of it. George tells Hedda that he is planning to return it and that she must tell no one that it is in his possession.

George then sees a letter which has been sent from his Aunt Juliana and knows that his sister is dying. Hedda promises to have the manuscript until George returns from visiting his aunt. Judge Brack then pays Hedda a visit and informs her that Eilert did not become drunk the night before but was indulged in a fight with Mademoiselle Diana, the red-haired singer whom Mrs. Elvsted mentioned in the first act. Missing his pocketbook and his manuscript, he blames her or her friends for robbery. In the fight that resulted Lovborg struck one of the police officers who came to calm the group. The Judge still wanted to arrange a love affair with Hedda and so he suggests that no decent household would admit Eilert Lovborg because of his bad conduct.

Lovborg enters and informs Mrs. Elvsted that he has destroyed the manuscript, and 
she leaves in distress. Lovborg confesses to Hedda that he has truly lost the manuscript. He made a firm decision to commit suicide, and Hedda offers him one of her pistols. He goes away as she tells him to do it "beautifully." (Act III, 286) After Eilert departs, Hedda moves to the stove and burns the manuscript, piece by piece, announcing that she is burning the child of Eilert and Thea.

In the evening of the same day when Act IV begins, Aunt Juliana tells the news of her sister's death to George and Hedda. George enquires Hedda for the manuscript, and she confesses that she burned it. Hedda states that she did it for his sake, and then indirectly admits that she is pregnant. She calls him George for the first time during the drama. He is not ecstatic about the news of her pregnancy that he ignored his anger about the manuscript.

Mrs. Elvsted comes to the Tesmans' home and tells that she is very worried about Lovborg. Judge Brack then brings the news of Eilert's death who has shot himself. Everyone is tensed by his death except Hedda. George is disappointed by the thought that Eilert and his manuscript are now gone. However, Thea provides a packet of notes from which Lovborg had dictated, George is delighted by this news and announces that he will not take rest until he and Thea reproduce the original manuscript.

Brack decides to reveal Hedda the real truth about Lovborg's death. He discloses the fact that Lovborg was not shot in the breast, as the Judge said earlier, but in the intestine. Hedda becomes very sad because she wanted him to die a "beautiful" death. She is at the height of despair as she declares that everything she touches turns ridiculous and mean.

The Judge reveals Hedda that the pistol found on Lovborg must have been stolen, but Hedda denies it. He tells her of the great danger of scandal she is now in, but he promises to save her if she will surrender to him. Hedda cannot suffer this thought and retires to her room where she plays a wild dance on the piano. When Hedda calls about to George to ask him about what she will do in the evening, now that he is so occupied, George refers that Judge 
Brack can keep her company. A shot is perceived from within, and George draws the curtains to see Hedda lying dead on the couch. As the curtain drops, Judge Brack calls out, "Good God: People don't do such things". (Act IV, 304)

Thus, the reason behind Hedda's suicide can be responsible to any number of causes. As it is evident to the reader, she has been internally discontent throughout the entire play. It is made clear that she is weary, unable to escape a monotonous marriage, emotionally subdued, and pregnant with a child which she clearly does not wish to have. However uncomfortable she has been however, she has managed to get by relatively well. Therefore, there are several possibilities as to what events lead her to finally end her own life. As Martin Esslin stated in his essay:

[Hedda's] sense of social superiority prevents her from realizing her genuine superiority as a potential creative personality. If the standards prescribed by the laws of noblesse oblige had not prevented her from breaking out into the freedom of moral and social emancipation, she might have been able to turn her passionate desire for beauty (which is the hallmark of real, spiritual, as distinct from social, aristocracy) to the creation of beauty, living beauty rather than merely a beautiful death. It is the creative energy, frustrated and damned up, that is finally converted into the malice and envy, the destructive rage, the intellectual dishonesty that lead to Hedda Gabler's downfall. ( Esslin, Martin. "Reflections: Essays on Modern Theatre".p. 39)

From another point of view however, she may have taken her own life to prove her courage; in doing so, she preserves her aesthetic ideologies (by dying "nobly"), frees herself of societal standards, and proves herself to judge Brack and her husband. By committing suicide, she thinks that she is proving that a noble death is actually possible, and that she is facing her fear of scandals, as what is more scandalous than spontaneous suicide? This is 
certainly the most optimistic explanation of her suicide, and one must also consider that perhaps she simply could find nothing to live for just before her suicide, Hedda asks George whether he wants her for anything, to which he replies: "No, nothing in the world" (Ibsen, Henrik. Hedda Gabler. Act IV, 423-424), giving her an aura of utter futility.

In conclusion, the character of Hedda Gabler is one with complex motives. Under harsh suppression from societal standards, in which one is shunned for the slightest act of imprudence, Hedda must resort to subtle manipulation and passive aggression in order to entertain herself and find something in her life worth living for, though why she is not satisfied with her life as a woman during the nineteenth century as Mrs. Elvsted supposedly is never truly realized. One might say that she is portrayed as a woman that is ahead of her time, though her fear of scandals and therefore her cowardice appear to trap her to her nineteenth century existence, one which she is content in abandoning.

"For it is an act of self-renunciation, in a dark and ironic sense, through which Hedda rings down her life; she does not die for another person... and she does not live for another person... she dies for herself as she had lived for herself. In that she dies, she proves herself to be among those free born, untamed creatures; for in the necessity of her death, there first is revealed the whole tragedy of the uncanny contradiction of Hedda Gabler: the tragic aspect is that Hedda may only prove to herself the true existence of her inner freedom by cancelling herself out. She extinguishes the life of the tame and false Hedda, caught in the meshes of her own weakness, who, while still living would not have found bearable the verdict now intoned by Counselor Brack over the deceased: "People don't do such things!" (Salome, Lou. Ibsen's Heroine. p. 24)

Another aspect is that Hedda struggles furiously against the conventional wife-mother role, a role she does not want but is mortally fear to reject. She suffers most from what Gail 
Finney called in The Cambridge Companion to Ibsen "victimization by motherhood"(Finney, Gail. "Ibsen and Feminism".); she is incapable to face or to escape the suffocating reality of marriage and motherhood. That assuredly is as big a factor in her self-destruction or selfrenunciation as is her fear of being held sexual hostage to the sinister judge Brack, who threatens to exhibit her to scandal, of which she is at least equally terrified.

More is read about Hedda than any of the other female characters. As Orley I. Holten defined in his work regarding Hedda Gabler:

"The important philosophical question which involves Hedda is whether to commit suicide. In the narrow world in which Hedda exists, she is forced to make a decision about the future. Unwanted, unfulfilled, and doomed to confinement, she feels that she has no other choice but to take her own life. Hedda has great possibilities, but, like many other people living in a modern world, she does not know how to realize her possibilities. In groping for a means to achieve self-satisfactions, she brings only destruction". (Holtan, Orley I. Mythic Patterns in Ibsen's Last Plays. p. 95)

That's why this controversial play has inspired generations of modernist writers with its scandalous content and nature, challenging the time in a courageous approach to themes such as morality, the value of individuals (particularly females) in contemporary society, motivation and monotony within conventional society and the conflicting decision of selfliberation or self renunciation. 


\section{Works Cited}

Berbohm, Max. “An Hypocrisy in Playgoing”. New York: Around Theatre, Simon and Schuster, 1954. pp. 277-81.

Esslin, Martin. "Reflections: Essay on Modern Theatre". Garden City, New York: Doubleday, 1969. p. 39.

Finney, Gail. "Ibsen and Femininism". The Cambridge Companion to Ibsen. ed. James McFarlane. New York: Oxford University Press, 1994. pp. 99-100.

Holtan, Orley I. Mythic Patterns in Ibsen's Last Plays. Minneapolis: University of Minnesota Press, 1970.p. 95.

Ibsen, Henrik. Hedda Gabler: Four Great Plays. Trans. Alyssa Harad. New York: Pocket Books, 2005.

Ibsen, Henrik. Hedda Gabler: Four Major Plays. Trans. Rolf Fjeldi. New York: Signet Classic, 1965.

Salome, Lou. Ibsen's Heroines. Trans. Siegfried Mandel. Redding Ridge, CT: Black Swans Books. 1985. p. 24.

Templeton, Joan. Ibsen's Women. New York: Cambridge University Press, 2001. p. 206. 